\title{
The Responsibility to Protect Internally Displaced Persons in Africa
}

\author{
Olivia Lwabukuna* \\ SOAS University of London, UK \\ Ol3@soas.ac.uk
}

\begin{abstract}
This article explores the responsibility to protect (R2P) as an organizing concept for preventing, addressing and finding durable solutions to internal displacement in Africa. While the most innovative norms for protecting the forcibly displaced have been conceptualized in Africa, they have not durably addressed displacement, due to limitations in implementation. R2P has similarly faced criticisms emanating from a lack of clarity and distrust. Restated norms underlying frameworks for internally displaced persons (IDPs) and R2P complement each other, and can be operationalized simultaneously through a more credible regional approach, to encourage effective protection of IDPs in Africa. The article explores pillar one, pillar two and the non-coercive elements of pillar three of R2P, and its underlying moral principles, using Kenya as a case study of the process of seeking to secure state responsibility for the protection of displaced civilians victimized by mass atrocities.
\end{abstract}

\section{Keywords}

IDPs, R2P, Africa, Kenya, post-election violence

\section{INTRODUCTION}

This article argues for marrying existing and emerging normative and institutional mechanisms related to the concepts of responsibility to protect (R2P) and internal displacement in Africa. It seeks to identify their convergency and / or complementarity, and utilizes this to set out a conceptual argument for state responsibility, within the context of preventing and responding to internal displacement. The post-election violence in Kenya in 2008 is explored as a pivotal case study on how the convergence of R2P norms and mechanisms for internally displaced persons (IDPs) can be employed collectively to prevent or address the plight of IDPs in Africa. The article also draws out the limitations and possibilities of such an approach, by highlighting the relevance of political interest and the importance and viability of regional, as opposed to

* LLB (Swaziland), LLM (Cape Town), LLD (Pretoria). Lecturer, School of Law, SOAS University of London; advocate (High Court of Tanzania). 
purely internationally driven operationalization, and emphasizing the limited replicability of this approach, due to its dependence on very specific contextual factors.

Engaging R2P within an internal displacement context is not new. ${ }^{1}$ However, most scholarly work has focused on either one or the other, failing to centre them simultaneously within a civilian protection context. Despite sovereignty as responsibility being recognized as an antecedent to R2P, and IDPs often being victims of crimes that fall within the ambit of R2P, the uptake of the R2P norm in protecting IDPs has been slow. ${ }^{2}$ Notwithstanding these gaps, the spirit of R2P is reflected in normative and institutional frameworks for civilian protection in Africa, including those on internal displacement. ${ }^{3}$ This best reflects Francis Deng's work, which pioneered both IDP protection and R2P through the concept of sovereignty as responsibility, eventually underpinning the UN Guiding Principles on Internal Displacement (UNGP).

The UNGP are the conceptual and legal foundations for a system to protect IDPs. ${ }^{4}$ They comprise what has been described as minimum international standards for the treatment of IDPs, by clarifying gaps and covering all phases, and causes, of internal displacement. ${ }^{5}$ The IDP system was contested from the

1 E Mooney "Something old, something new, something borrowed ... something blue? The protection potential of a marriage of concepts between R2P and IDP protection" (2010) 2/1 Global Responsibility to Protect 60 at 63; R Cohen "Reconciling R2P with IDP protection" (2010) 2 Global Responsibility to Protect 15 at 20.

2 Mooney, ibid.

3 The African Union (AU) Constitutive Act, 2001, OAU doc CAB/LEG.23.15 (Constitutive Act), adopted by the 36th ordinary session of the Assembly of Heads of State and Government, 11 July 2000, Lomé, Togo, art 4(h); Protocol relating to the Establishment of the Peace and Security Council of the AU (PSC Protocol), adopted at the first ordinary session of the AU Assembly, 9 July 2002, Durban, South Africa, art 7(e); The AU Convention for the Protection and Assistance of IDPs in Africa (Kampala Convention), adopted by the Special Summit of the AU, 23 October 2009, Kampala, Uganda, art 8; International Conference on the Great Lakes Region (ICGLR) Protocol to the Pact on Security, Stability and Development in the Great Lakes Region (GLR) on the Protection and Assistance to IDPs (GLR IDP Protocol), adopted 30 November 2006, Nairobi, Kenya; E Luck "Sovereignty, choice and the responsibility to Protect" (2009) 1 Global Responsibility to Protect 10 at 15; UN Guiding Principles on Internal Displacement, 1998 (E.CN.4/1998/53/Add.1) (E/CN.4/1998/53/Add.2), principles 3 and 25. The Guiding Principles reflect a wider ambit of human rights protection than the R2P principle, or art 4(h) of the Constitutive Act, which are limited to mass atrocities. For a disambiguation of the relationship between R2P, art $4(\mathrm{~h})$ and the protection of civilians, see D Kuwali "Article 4(h), the responsibility to protect and the protection of civilians" in D Kuwali and F Viljoen (eds) By All Means Necessary: Protecting Civilians and Preventing Mass Atrocities in Africa (2017, PULP) 16 at 24-26.

4 "IDPs" is not a closed description, but a factual state that triggers legal consequences: Protecting Internally Displaced Persons: A Manual for Law and Policy Makers (2008, Brookings Institution) at 11.

5 L Juma "The narrative of vulnerability and deprivation in protection regimes for internally displaced persons (IDPs) in Africa: An appraisal of the Kampala Convention" (2012) 16 Law Democracy and Development 219 at 226; UNGP, Introduction, para 3. These gaps 
outset, but it was eventually agreed that a distinctive regime for their protection was needed. ${ }^{6}$ The need for IDP protection emanating from civil wars, forced relocation and serious human rights abuses required a rethink in approaches to sovereignty, humanitarian action and operations. ${ }^{7}$ Francis Deng, the first UN Secretary-General's (UNSG) representative on the human rights of IDPs, negotiated for a protection system that balanced these concerns by emphasizing the need to re-configure and re-understand sovereignty, not just as a right, but also a duty. ${ }^{8}$ He said:

\begin{abstract}
"Sovereignty as responsibility posits primary responsibility for the welfare and safety of IDPs with their governments. However, when governments are unable to fulfil their responsibilities, they should request and accept offers of aid from the international community. If they refuse or deliberately obstruct access and put large numbers at risk, the international community has a right and even a responsibility to take a series of calibrated actions. These range from 'diplomatic demarches to political pressures, sanctions, or, as a last resort, military intervention'. State failure to provide protection and life-supporting assistance 'legitimized the involvement of the international community'."
\end{abstract}

Pillar one of R2P, which first conceptualized sovereignty as responsibility, assigns the main responsibility for the welfare and safety of civilians (including IDPs) to their states. If unable to fulfil their obligations, states are required to request, be offered and accept support from the community of nations, as pillar two prescribes. ${ }^{10}$ Pillar three dictates that any unwillingness or deliberate obstruction of access, resulting in protection or material risk to civilians (including IDPs) constitutes grounds for timeous and decisive intervention

contd

include consensus, applicability and ratification gaps: FM Deng "The plight of the internally displaced: A challenge to the international community" (2004) at 2, available at: <https://www.brookings.edu/wp-content/uploads/2016/06/20040408plight.pdf> (last accessed 12 December 2020).

6 UN High Commission for Refugees (UNHCR) "Internally displaced persons" in The State of the World's Refugees: Human Displacement in the New Millennium (2006, Oxford University Press) 153 at 166-67; Cohen "Reconciling R2P", above at note 1 at 17. See S Ogata The Turbulent Decade: Confronting the Refugee Crisis of the 1990s (2005, WW Norton \& Company) at 38. See also Javier Perez de Cuellar, former UN Secretary-General, as quoted in R Cohen and F Deng Masses in Flight: The Global Crisis of Internal Displacement (1998, Brookings Institution) at 1.

$7 \mathrm{~T}$ Weiss and D Korn Internal Displacement: Conceptualization and its Consequences (2006, Routledge) at 11 and 29.

8 Cohen and Deng Masses in Flight, above at note 6 at 24; F Deng "The impact of state failure on migration" (2004) 15/4 Mediterranean Quarterly 16 at 17.

9 Cohen and Deng, id at 7. See also F Deng Protecting the Dispossessed: A Challenge for the International Community (1993, Brookings Institution) at 14-20; Deng et al Sovereignty as Responsibility: Conflict Management in Africa (1996, Brookings Institution) at 2-19 and 27-33.

10 Cohen "Reconciling R2P", above at note 1 at 20. 
from the international community under the umbrella of the UN Security Council, possibly cascading through to regional organizations. ${ }^{11}$ Such intervention could range from diplomatic efforts, political pressure and sanctions, to military efforts. The legal obligation to protect civilians lies with their government as its state responsibility. R2P facilitates meeting such responsibility. Accordingly, "the obligation imposed on states by humanitarian and human rights law to refrain from refusing reasonable offers of international assistance, makes it difficult to dispute the existence of a duty to accept such offers". ${ }^{12}$

The reconciliation of these analogous principles of sovereignty and fundamental human rights was institutionalized through international norm setting initiatives, ${ }^{13}$ and eventually reflected in African frameworks. ${ }^{14}$ R2P norms within African Union (AU) frameworks are more than an organizing political principle. They generate collective legal obligations for AU member states to respond to mass atrocity crimes, because they are embedded in the AU Constitutive Act (Constitutive Act), signed by all member states. ${ }^{15}$

This elevates the states' obligations for civilian protection and nondiscrimination that underpin the AU framework. ${ }^{16}$ It also emphasizes the acknowledgement, within the context of the framework, including the AU Convention for the Protection and Assistance of Internally Displaced Persons in Africa (Kampala Convention), that states take primary, but not exclusive, responsibility for protecting and assisting IDPs. ${ }^{17}$ This recognizes that, in

11 Constitutive Act, art 3(f).

12 Cohen and Deng Masses in Flight, above at note 6 at 277.

13 UNSG, K Annan Annual Report to the UN General Assembly (GA), SG/SM/7136 GA/9596 (20 September 1999) at 20; The Responsibility to Protect (report of the International Commission on Intervention and State Sovereignty, 2001, International Development Research Centre) at 6; GA World Summit Outcome 2005 res A/RES/60/1 (24 October 2005), paras 138-39; GA res 1674 (April 2006); GA res 1261 and 1325 condemning the deliberate targeting of internally displaced children and women; and GA res 1400 extending the mandate of the UN in Sierra Leone for the protection of IDPs, specifically mentioning R2P in this context.

14 A Bellamy "Realizing the responsibility to protect" (2009) 10/2 International Studies Perspective 111 at 122; R Thakur United Nations, Peace and Security: From Collective Security to the Responsibility to Protect (2006, Cambridge University Press) at 255; G Evans The Responsibility to Protect: Ending Mass Atrocity Crimes Once and For All (2009, Brookings Institution) at 36-38.

15 Kuwali "Article 4(h), the responsibility to protect", above at note 3 at 22 and 23; Kampala Convention, art $4(\mathrm{~h})$ and $(\mathrm{j})$.

16 P Orchard Protecting the Internally Displaced: Rhetoric and Reality (2019, Routledge) at 7; C Beyani "State responsibility for the prevention and resolution of forced population displacements in international law" (1995) 7 International Journal of Refugee Law 130 at 132; International Law Commission Draft Articles on Responsibility of States for Internationally Wrongful Acts (2001) Supp No 10 (A/56/10), arts 9 and 10; AM Abebe The Emerging Law of Forced Displacement in Africa: Development and Implementation of the Kampala Convention on Internal Displacement (2017, Routledge) at 10; Kampala Convention, arts 5(1) and 9(1)(a); UNGP, principle 3(1).

17 Kampala Convention, preamble and art 5(1); UNGP, ibid. 
certain cases, states may be unable or unwilling to do so. ${ }^{18}$ Such states are required to request support and co-operate with necessary actors in order to protect and assist IDPs, failing which collective action is justified. ${ }^{19}$ Such action would be operationalized within the context of article 8(1) and (2) of the Kampala Convention, which prescribes AU intervention.

The Kampala Convention is largely based on provisions of the UNGP, integrating international human rights and humanitarian law norms as they relate to internal displacement. It also incorporates principles from African regional instruments, such as the African Charter on Human and Peoples' Rights, and the International Conference of the Great Lakes (GLR) IDP Protocol, giving it an African character, in response to the unique African context. ${ }^{20}$ The GLR process that occasioned the 2006 Pact on Security, Stability and Development in the Great Lakes Region (GLR Pact) and IDP protocol, was an intergovernmental process set up to address peace, security and development. As a collectively binding norm-making platform, accountability measures accompanied its framework to ensure adoption, domestication and implementation. ${ }^{21}$ The GLR has taken noteworthy steps in attempting to redress the protracted and cyclic crises of internal displacement. The sub-region is also the first in Africa to have done so. Subsequently, lessons from the process and ensuing initiatives have influenced the AU continent-wide framework on international justice, peace and security, including responses to internal displacement. $^{22}$

This article highlights that evolving R2P and IDPs regimes within the African context have conceptually, legally and morally made a crucial and distinctive contribution to the development of law in this area. It shows that such efforts predate global responses to internal displacement and are influenced by the genealogy of African states, which were always conscious of, and highly fraught by, the crisis of displacement. The article goes beyond existing work in this field by using Kenya as a case study to show how developments of both R2P and IDPs regimes have been uniquely elaborated and implemented in Africa to enhance civilian protection. Simultaneously, this case study

18 Kampala Convention, art 5(2), (3), (6) and (7).

19 Ibid. This happens where mass atrocity crimes are proven to have been systematic and planned. Not all IDP situations justify R2P action. The GLR intervention framework offers wider protection than the AU intervention framework.

20 M Asplet and M Bradley "The African Union Convention for the Protection and Assistance of Internally Displaced Persons in Africa (Kampala Convention)" (2013) 52/1 International Legal Materials 397 at 397; Kampala Convention, preamble; The African Charter on Human and Peoples' Rights, adopted 27 June 1981, entered into force 21 October 1986, OAU doc CAB/LEG/67/3, rev 5; GLR IDP Protocol.

21 These measures included: ensuring IDPs' participation in norm domestication; regional programmes of action; regional follow-up mechanisms; and a coordinating committee. See D Clancy "Lessons from a state of flux: The International Justice Laboratory of the Great Lakes Pact" in L Oette Criminal Law Reform and Transitional Justice: Human Rights Perspectives for Sudan (2016, Routledge) 197 at 199.

Clancy, ibid. 
highlights the protection potential, effectiveness and limitations of rallying for IDP protection through R2P. The "successful" invocation of the norm in Kenya is widely contested. ${ }^{23}$ Criticism has focused on the failure to anticipate and prevent post-election violence, overlooking the nuanced responsibility to react and rebuild. This article posits that, while prevention is an important aspect of protection, including, under certain circumstances, obligating the due diligence of states to take all reasonable prevention measures, ${ }^{24}$ Kenya teaches us not to overlook other dimensions of R2P short of military intervention, when prevention is no longer possible, especially within displacement contexts.

\section{CHASTENED SOVEREIGNTY AND COLLECTIVE RESPONSIBILITY IN AFRICA}

\section{Reconciling sovereignty with collective responsibility to protect civilians in Africa}

Conflict-led mass atrocities in Africa, as in other parts of the world, precipitated the process of reconciling sovereignty with the protection of civilians, by committing to collective intervention. ${ }^{25}$ In some of these conflicts, including in Rwanda, African countries were forced to fend for themselves, due to delayed and politicized responses from the international community. ${ }^{26}$ Consequently, the Organisation of African Unity (OAU) Summit in Tunis in $1994^{27}$ presented an opportunity for the OAU (the AU's predecessor) to articulate, for the first time, a system of collective responses to prevent, respond to and rebuild after mass atrocities. "Rwanda stands out as a stern and severe rebuke for all of us for having failed to address Africa's security problems. As a result of that, a terrible slaughter of the innocent has taken place, and is taking place in front of our very eyes. We know it is a matter of fact that we must have it in ourselves as Africans to change all this. We must, in action assert our will to do so." 28

23 Cohen "Reconciling R2P", above at note 1 at 21; S Sharma "The 2007-2008 post-election crisis in Kenya: A success story for the responsibility to protect" in J Hoffman and A Nollkaemper (eds) Responsibility to Protect: From Principle to Practice (2012, Pallas Publication) 27 at 30.

24 S Rosenberg "Responsibility to protect: A framework for prevention" (2009) 1 Global Responsibility to Protect 442 at 443.

25 S Dersso "The African Union's agenda on the protection of civilians: A review of its ambition and practice" in Kuwali and Viljoen (eds) By All Means Necessary, above at note 3, 394 at 396. Cases in point are Somalia, Democratic Republic of Congo, Liberia, Sierra Leone and Rwanda.

26 A Adebanjo The Curse of Berlin: Africa After the Cold War (2010, Hurst) at 40.

27 A Abass and M Baderin "Towards effective collective security and human rights protection in Africa: An assessment of the Constitutive Act of the new African Union" (2002) 49/1 Netherlands International Law Review 1 at 6.

28 N Mandela, as quoted in R Omaar and A De Waal Rwanda: Death, Despair and Defiance (1995, African Rights) at 1138. See also Dersso “The African Union's agenda”, above at note 25 at 398. 
In the years that followed, when Africa's Peace and Security Architecture was being established, these views were reiterated by the first AU commissioner for peace and security: "[n]o more, never again. Africans cannot watch the tragedies developing on the continent and say it is the UN's responsibility or somebody else's responsibility. We have moved from the concept of non-interference to non-indifference. We cannot as Africans remain indifferent to the tragedy of our people." 29

The acknowledgement of R2P by African governments has evolved substantially. With the exception of Zimbabwe, ${ }^{30}$ sub-Saharan African states were particularly avid supporters of the adoption of resolution $1674,{ }^{31}$ which reaffirmed the UN World Summit's provisions on the doctrine of R2P. ${ }^{32}$ States like Rwanda insisted on the "necessity of collective R2P", while Benin "signalled its full support" and Tanzania, with some reserve, endorsed R2P, insisting that "when governments fail or are unable to offer such protection, we should have a collective responsibility to protect humanity". ${ }^{33}$ A similar view was shared by South Africa, Ghana and Republic of Congo. ${ }^{34}$ This approach has resulted in a strong civilian protection agenda, including frameworks set up to address internal displacement in Africa.

\section{Normative and institutional aspects of collective responsibility in Africa}

Starting with the transformation of the OAU to the AU, the centrality of the agenda for the collective protection of civilians has been echoed in the institutional and normative systems of the AU, as it has on the global stage. ${ }^{35}$ The institutional aspect has been reflected through the architecture for African peace and security. The main pillar of this architecture is the Peace and Security Council, provided for by the 2002 Protocol to the Constitutive Act on Peace and Security (PSC Protocol). ${ }^{36}$ The normative aspect emphasizes the re-conceptualization of sovereignty, echoing provisions of the International Commission on Intervention and State Sovereignty (ICISS) framework, which conceptualized sovereignty as follows: "[s]overeign states have the primary responsibility for the protection of their people from avoidable catastrophe,

29 Ambassador S Djinnit, AU Peace and Security Commissioner, quoted in K Powell "The African Union's emerging peace and security regime: Opportunities and challenges for delivering on the responsibility to protect" (2005, ISS monograph no 119) at 1 . See also Dersso, ibid.

30 Bellamy "Realizing the responsibility", above at note 14 at 113.

31 S/RES/1674 (28 April 2006).

32 Bellamy "Realizing the responsibility", above at note 14 at 114 .

33 Ibid.

34 Id at 114 and 115.

35 OAU Sirte Declaration of 9 September 1999; Constitutive Act, preamble, arts 3(h) and (g) and 4(o), (m) and (h); PSC Protocol, preamble; OAU 37th summit, Report of the Secretary-General on the Implementation of the Sirte Summit Decision on the AU, OAU doc AHG/Dec, 1(v) (9-11 July 2001).

36 The PSC Protocol was adopted in line with Constitutive Act, art 5(2). 
from mass murder, rape, starvation ... but when they are unable or unwilling to do so, the responsibility must be borne by the wider community of states".37

This framework reflects Deng's three pillars, which became a cornerstone of his conceptualization of "sovereignty as responsibility", as a basis for garnering global consensus on IDP protection and, eventually, collective responsibility through R2P. ${ }^{38}$ For African states, collective responsibility is re-constituted regionally, as anticipated under the UN Charter. ${ }^{39}$ Echoed within the common African position on R2P (Ezulwini Consensus), African states have clarified their commitment to implementing R2P through the AU. ${ }^{40}$ So far, such implementation has prioritized pillars one and two, as well as non-coercive elements of pillar three, which are less political, over the often forceful militaristic elements. ${ }^{41}$

This development has constituted a drastic turn away from earlier interpretations of principles of sovereignty and non-intervention, which had prioritized state security, territorial integrity and political authority to the detriment of human security. ${ }^{42}$ The definition of sovereignty has strongly metamorphosed to reiterate, reassert and re-emphasize the obligations and duties of individual and collective sovereign states towards the protection and upholding of citizens' and residents' rights. ${ }^{43}$ Responsible sovereignty, which is the political and intellectual capital of the R2P doctrine, departs from the narrower idea of humanitarian intervention, which is statecentred. ${ }^{44}$ Instead, R2P is victim oriented; it introduces a culture of national and international accountability and is a mobilization tool to effect timely reaction to humanitarian crises. ${ }^{45}$

37 The Responsibility to Protect, above at note 13 at 6.

38 World Summit Outcome res, above at note 13, paras 138 and 139; Kuwali "Article 4(h), the responsibility", above at note 3 at 21. The World Summit Outcome res also notes the possibilities of the R2P framework in respect of IDPs, and the bolstering of their protection through the UNGP.

39 UN Charter (24 October 1945) 1 UNTS XVI, chap VIII, arts 52(2) and 53(1).

40 The Common African Position on the Proposed Reform of the UN: The Ezulwini Consensus, Executive Council seventh extraordinary session, 7-8 March 2005, Addis Ababa, Ethiopia: Ext./EX. CL/2 (VII) 6.

41 J Iyi "Emerging powers and the operationalisation of R2P in Africa: The role of South Africa in the UNSC" (2014) 7/1 African Journal of Legal Studies 149 at 160.

42 Charter of the OAU, adopted 25 May 1963, Addis Ababa, Ethiopia, entered into force 25 October 1965, art 3(1), (2), (3) and (5); C Clapham Africa and the International System: The Politics of State Survival (1996, Cambridge University Press) at 110-11; D Wemboue "The OAU and international law" in Y El Ayouty The Organization of African Unity After Thirty Years (1994, Praeger) 15 at 17; Abbas and Baderin "Towards effective collective security", above at note 27 at $9-13$.

43 Deng "The impact of state failure", above at note 8 at 17.

44 A Bellamy Responsibility to Protect: The Global Effort to End Mass Atrocities (2009, Polity Press) at 111.

45 Center for Conflict Resolution (CCR) "Africa's responsibility to protect” (Policy Advisory Group seminar report, 23-24 April 2007, Somerset West, South Africa) at 7. 
In Africa the re-conceptualization of absolute sovereignty is also rooted in the African Charter on Human and Peoples' Rights. ${ }^{46}$ Traces of this view can be found in the Universal Declaration of Human Rights, as well as the International Covenant on Economic, Social and Cultural Rights, among others. ${ }^{47}$ Unlike under the OAU Charter, the objectives and principles of the Constitutive Act reflect the strong democratic and human rights content found in the above human rights instruments, by emphasizing the promotion and protection of human and peoples' rights and the sanctity of human life, dignity and freedom. ${ }^{48}$ These instruments refer to the will of the people as a basis for government authority and good governance. ${ }^{49}$ This has further made it necessary to re-assert the self-determination doctrine, which in effect demands respect for people's sovereign rights over a state's sovereignty. As Depaigne puts it, "[t]he sovereign is no longer the king, but the nation. Sovereignty is tied to human rights. The sovereign derives its legitimacy from the freedom and well-being of its constituent parts, the individuals. This relation is reciprocal, human rights legitimize the sovereignty of a nation and, in turn, this sovereignty legitimizes human rights". ${ }^{50}$

The AU's new institutional framework requires all its members to observe these fundamental values and standards, in addition to democratic governance and the discouragement of unconstitutional changes of government. ${ }^{51}$ A state that fails to do so may face, inter alia, political and economic sanctions. ${ }^{52}$ The AU Assembly, the union's supreme organ, ${ }^{53}$ is responsible for deciding on intervention through article $4(\mathrm{~h})$ of the Constitutive Act. This article sets out a new paradigm of human rights, collective responsibility and intervention within the context of peace, security and international justice, specifically in cases involving genocide, crimes against humanity and war

46 B Kioko "The right of intervention under the African Union's Constitutive Act: From non-interference to non-intervention" (2003) 85 International Review of the Red Cross 807 at 820; African Charter on Human and Peoples' Rights, art 20(1). The charter affirmed the right to equal protection of the law, without discrimination (arts 3.2 and 2), the right to freedom of movement and residence (art 12.1) and the right to respect for human dignity (art 5), and prohibited all forms of exploitation and degradation of man (art 5). It also affirmed the right to liberty and security (art 6).

47 The Universal Declaration of Human Rights, GA res 217 A(III) (10 December 1948), art 21(3); and the International Covenant on Economic, Social and Cultural Rights, GA res 2200A (XXI) (16 December 1966), art 1.

48 Constitutive Act, arts 3(e), (h) and (g), and 4(m), (o), (h) and (j); Deng et al Sovereignty as Responsibility, above at note 9 at 1.

49 Deng et al, id at 4.

50 V Depaigne "Dis-locating sovereignty? States, self-determination and human rights" (2007) 10 The Bologna Center Journal of International Affairs 35 at 37.

51 Kioko "The right of intervention", above at note 46 at 807.

52 Constitutive Act, art 23(2).

53 Id, art 6. 
crimes (mass atrocities). A co-relating duty is placed upon states to request intervention from the AU in order to restore peace and security. ${ }^{54}$

The Constitutive Act's amending protocol closely mirrors these norms by empowering the Peace and Security Council (PSC) to make recommendations to the AU Assembly to intervene where the necessary and usual provisions for intervention do not apply, but circumstances require it. ${ }^{55}$ This has effectively widened the ambit of intervention, going beyond mass atrocity crimes, to include situations that are not classic R2P, but where there is a threat to legitimate order or peace and security. The PSC Protocol reiterates these provisions for intervention in its articles $7(\mathrm{e}), 4(\mathrm{j})$ and $4(\mathrm{k}){ }^{56}$ These norms were eventually reflected in the Kampala Convention, which cross-references the AU's intervention right and duty. ${ }^{57}$ Cross-reference between the AU civilian protection and intervention framework, and the Kampala Convention, strengthens arguments for collective responsibility as an implementation tool for IDP protection regimes. This has created a normative, institutional and enforcement system for civilian protection, including what could be considered a duty to ensure favourable conditions for finding durable solutions to internal displacement.

In-depth African conceptualization of R2P is also seen in the way the Constitutive Act embraces the three levels of action prescribed by the ICISS report. ${ }^{58}$ These include: prevention, reaction and post-conflict reconstruction within the three pillars of responsibility; at state level, through support and capacity building; and collective action in the event of inability or unwillingness to act. ${ }^{59}$ Pursuant to this, the PSC was created in 2004. This 15-member council supports the prevention, management and resolution of conflicts on the continent. It functions as a form of collective security and early warning system that provides timely and effective responses by the AU to conflict situations. The PSC is a source of authority on intervention on the basis of

54 Id, art 4(j).

55 Such circumstances include serious threats to legitimate order or restoring peace and security. Kioko "The right of intervention", above at note 46 at 815 ; Protocol on Amendments to the Constitutive Act of the AU, adopted at the first extraordinary session of the AU Assembly, Addis Ababa, Ethiopia, 3 February 2003 and by the second ordinary session of the AU Assembly, Maputo, Mozambique, 11 July 2003; Kampala Convention, art $8(1)$.

56 Similar principles are recognized within it as a basis for intervention, including, where the AU Assembly deems so, in respect of grave circumstances, namely war crimes, genocide and crimes against humanity (as per the Constitutive Act, art 4(h)) or where there is a request by a member state in order to restore peace and security, in accordance with art $4(\mathrm{j})$ of the Constitutive Act.

57 The convention spells out the AU's obligations, including reiterating its rights to intervene under art $4(\mathrm{~h})$ of the Constitutive Act, and the obligation to respect a member state's right to request intervention as a way of contributing to the creation of favourable conditions for finding durable solutions to the problem of internal displacement.

58 The Responsibility to Protect, above at note 13.

59 CCR "Africa's responsibility to protect", above at note 45 at 20. 
civilian protection against mass atrocities, during times of crisis and peace, as an implementer of article $4(\mathrm{~h})$ and $(\mathrm{j})$ of the Constitutive Act. PSC subsidiary bodies set up to support this task include the Peace Fund, Early Warning System, the Panel of the Wise and Africa's Standby Force. These institutional capacities of the PSC are collectively the foundation for implementing the two dimensions of R2P: prevention and reaction. ${ }^{60}$ Article 14 of the PSC Protocol outlines the institutional capacity for peace-building, which reflects the third R2P dimension of post-conflict reconstruction, in line with the AU Policy on Post Conflict Reconstruction and Development. Under this article, the PSC is empowered to undertake activities that include the resettlement and reintegration of refugees and IDPs, as well as providing assistance to vulnerable persons, closely mirroring the role of the UN peacebuilding commission. ${ }^{61}$ The PSC's role reflects a common understanding that protection, assistance and finding durable solutions to displacement, can prevent further displacement and future crises, thus maintaining peace and security.

\section{R2P AND THE EVOLVING DISPLACEMENT FRAMEWORK IN AFRICA}

The OAU had co-existed with humanitarian crises and forced displacement from its inception. Consequently, in June 1969, the OAU adopted the Convention Governing the Specific Aspects of Refugee Problems in Africa (OAU Refugee Convention), ${ }^{62}$ which was anchored in the then exemplary African culture of generosity and solidarity, as a pan-African solution to the refugee crisis on the continent. The Pan-African Conference on the Situation of Refugees in Africa and follow-up international conferences and high-level meetings on refugees in and on Africa reinforced basic humanitarian and solidarity principles elaborated in the OAU Refugee Convention. ${ }^{63}$ Since then, the OAU / AU has convened several sessions ${ }^{64}$ to elaborate these humanitarian

60 Ibid.

61 The PSC Protocol recognizes the relationship between conflict and forced displacement, provides for the role of the PSC in humanitarian co-ordination and also explicitly acknowledges that conflicts have forced millions of people in Africa, including women and children, to flee.

62 Adopted 10 September 1969, entered into force 20 June 1974, 1001 UNTS 45; M Sharpe The Regional Law of Refugee Protection in Africa (2018, Oxford) at 5.

63 Regional refugee instruments and related recommendations from the Pan-African Conference on the Situation of Refugees in Africa, Arusha (Tanzania), 17 May 1979; Report of the Secretary-General, International Conference on Assistance to Refugees in Africa, Geneva, 11 June 1981, A/36/316; Report of the Secretary-General, Second International Conference on Assistance to Refugees in Africa, Geneva, 9-11 July 1984, A/39/402; Oslo Declaration and Plan of Action, adopted 9 June 1999; OAU Khartoum Declaration on Africa's Refugee Crisis, 24 September 1990, BR/COM/XV/55.90.

64 For example, the Addis Ababa Document on Refugees and IDPs, 1994, adopted by the OAU/UNHCR Symposium on Refugees and Forced Population Displacements in Africa, 8-10 September 1994, Addis Ababa, Ethiopia. 
and solidarity principles. These efforts culminated in the 2009 Kampala Plan of Action on Forced Displacement in Africa, pronounced through the Kampala Declaration. ${ }^{65}$

The Kampala Declaration became a foundation for the Kampala Convention. ${ }^{66}$ This convention is a landmark instrument that has established common regulatory standards for IDPs in Africa by consolidating existing norms, while breaking new ground. It relies heavily on the UNGP and reflects them in its preamble, while regarding them as a legal source of its principles and objectives. It goes beyond them to provide non-exhaustively for displacement factors unique to the African context, including harmful practices, unregulated development projects and people with special attachment to land. ${ }^{67}$ Lastly, it clarifies obligations for states, the AU, international and humanitarian organizations, as well as non-state actors, grounding itself on state responsibility and the responsibilities of other actors and entities. ${ }^{68}$

Elaboration of the right not to be arbitrarily displaced, underscores the novelty of these provisions. By broadly and non-exhaustively outlining acts that are deemed to violate the right, the Kampala Convention goes beyond delineations of this existing right in international law, to respond specifically to forced displacement in Africa. Even though arbitrary displacement is considered a harm rather than a crime under the convention, acts of arbitrary displacement that amount to genocide, war crimes or crimes against humanity are required to be declared by states as offences punishable by law. A corresponding obligation is placed on states to ensure responsibility for acts of arbitrary displacement. ${ }^{69}$ In emphasizing IDPs' rights, and the responsibilities of governments and the international community, the right not to be arbitrarily displaced elevates IDP protection from a moral imperative to a legal duty, the violation of which calls for state accountability. ${ }^{70}$

The obligations the Kampala Convention places on relevant actors are in line with the principles underlying R2P, starting with obliging member states to protect populations from internal displacement and to prevent it. ${ }^{71}$ It then obliges member states, as the foremost bearers of responsibility for protection and assistance during displacement, to ask for support where they are incapable of providing what is required. ${ }^{22}$ This is coupled with placing obligations

65 The Kampala Declaration on Refugees, Returnees and IDPs in Africa calls on and declares the AU's intention to address various facets of displacement, including that of internal displacement.

66 The Kampala Convention came into force on 6 December 2012, with 31 ratifications and 40 signatures as of 14 December 2020, and is the first binding legal framework in the world related to IDPs.

67 Id, arts 4(4), 10 and 4(5).

68 Id, arts 2(d), 2(e), 3, 4, 5, 6, 7(5), 8 and 9.

$69 \mathrm{Id}$, art $3(1)(\mathrm{g})(\mathrm{h})$ and (i).

70 UNGP, principles 3, 25 and 27; Kampala Convention, arts 3 and 4.

71 Kampala Convention, arts 3 and 4.

72 Id, arts 5-9. 
on the AU to: support member states in protection efforts; respond to member states that request intervention in accordance with article $4(\mathrm{j})$; or take bold steps to intervene pursuant to article $4(\mathrm{~h})$ where the states are unwilling to request support, but IDPs' needs require it. ${ }^{73}$ Embedded within these provisions are core pillars of R2P, first shouldered by the state, then a duty to support and assist by a collective of African states, followed by a collective responsibility to react and intervene where the circumstances call for it in accordance with relevant law. The responsibility to reconstruct and rebuild, while not so obvious, can be extrapolated from provisions of the convention on durable solutions and compensation. ${ }^{74}$

The Africa-wide approach to preventing and addressing internal displacement through collective responsibility owes its genesis to initiatives taken within the GLR. This region was the first in Africa where, in the mid-1990s, the UN Security Council invoked chapter VII powers to authorize humanitarian intervention to respond to the internal displacement of persons, refugees and civilians at risk. ${ }^{75}$ Internal displacement within the sub-region has been persistent, protracted, cyclic and a constant consequence of conflict and unregulated projects. These realities have led to the sub-region's responses preceding and influencing the AU continental approach. The sub-region is not only one of the parts of the world most affected by the phenomenon of IDPs, but it is also one of the few regions that sought to develop a legal and political framework for holistically addressing matters of peace, security and development, including the issue of internal displacement. ${ }^{76}$

The GLR Pact consists of a set of legal frameworks, programmes of action and mechanisms that bear, among other things, collective commitments to integrate economically, but also undertake mutual defence and R2P within the context of international criminal justice. ${ }^{77}$ At least ten of the protocols that make up the GLR Pact reflect responses to mass atrocities, including R2P trigger factors, which are consequences or causes of forced displacement. ${ }^{78}$ These, and the peace and security elements of the pact, constitute a toolbox for preventing and addressing mass atrocities for GLR member states

73 Id, art 8(1), (2) and (3).

74 Id, arts 11 and 12; Clancy "Lessons from a state of flux", above at note 21 at 198.

75 UN Security Council res S/RES/925 (8 June 1994), paras 4 and 5; and res S/RES/929 (22 June 1994), paras 3 and 4.

76 UN Security Council res 1291 and 1304 on the establishment of the ICGLR.

77 In the Interests of Justice? Prospects and Challenges for International Justice in Africa (International Refugee Rights Initiative report, 2008) at 45, available at: <http://www. vrwg.org/downloads/in-the-interests-of-justice.november-2008.pdf> (last accessed 12 December 2020).

78 These are the: Protocol on the Protection and Assistance of Internally Displaced Persons; Protocol on the Property Rights of Returning Persons; Protocol on the Prevention and Suppression of Sexual Violence Against Women and Children; Protocol on the Prevention and Punishment of the Crimes of Genocide, War Crimes and Crimes Against Humanity; Protocol on Democracy and Good Governance; Protocol on Judicial Cooperation; Protocol on Non-Aggression and Mutual Defence in the GLR; Protocol on 
individually and collectively. ${ }^{79}$ The GLR IDP Protocol was the first common sub-regional binding framework in Africa or the World to define roles and responsibilities for a wide range of stakeholders operating in displacement settings. Its objective is to establish frameworks in which the UNGP can be adopted. Together with the GLR Pact, it obliges member states to incorporate the UNGP into their national legislation as a goal for achieving commonality in peace and stability, reconstruction and development. ${ }^{80}$ The Kampala Convention drew heavily on the UNGP, but also borrowed from the GLR IDP Protocol, taking its provisions a step further. In addition to defining who an IDP is, the convention defines the process of internal displacement as "[t]he involuntary, or forced movement, evacuation or relocation of persons or groups of persons within internationally recognized State borders". ${ }^{81}$

Both the UNGP and the GLR IDP Protocol failed or avoided to define the process of displacement itself. Defining the process recognizes additional factors, such as forced evacuation or relocation, and thus easily provides for situations of forced eviction or transfers that are hardly recognized as internal displacement triggers, but are prohibited under international humanitarian law. ${ }^{82}$ Thus, the Kampala Convention provides wider protection in line with international law, and this extends to its recognition of environmental disasters and development as displacement factors. ${ }^{83}$ The GLR IDP Protocol incidentally extends this by definitively including development within its definition of IDPs, ${ }^{84}$ unlike the UNGP ${ }^{85}$ or the Kampala Convention.

The GLR Pact has been instructive for the wider African process of intervention to protect civilians at risk by incorporating special provisions for the forcibly displaced. This has included addressing atrocity crimes like genocide, war crimes and crimes against humanity, including ethnic cleansing, which constitute R2P trigger elements, and are factors causing displacement. For instance, in terms of these atrocity crimes, the pact through relevant laws

contd

Management of Information and Communication; Protocol Against the Illegal Exploitation of Natural Resources; and Protocol on the Specific Reconstruction Zone.

"Some reflections on the legal and political mechanisms bolstering the responsibility to protect: The African Union and the Great Lakes, Eastern, Southern and Horn of Africa sub-regional arrangements" (International Refugee Rights Initiative), available at: <http://refugee-rights.org/wp-content/uploads/2019/02/Some-reflections-IRRI-FINALR2P-REC-paper.pdf> (last accessed 12 December 2020).

80 L Mulamula "Genocide prevention: Experience of the International Conference on The Great Lakes Region (ICGLR) Regional Forum on Genocide Prevention” (3-5 March 2010, Arusha, Tanzania) (copy on file with the author).

81 Kampala Convention, art 1(i).

82 The Fourth Geneva Convention bans individual or mass forcible transfers in article 49. See Protocol Additional to the Geneva Conventions, below at note 111; and Second Geneva Protocol, below at note 111, art 17.

83 Kampala Convention, arts 9 and 10.

84 GLR IDP Protocol, art 1; Cohen and Deng Masses in Flight, above at note 6 at 17.

85 UNGP, principle $6(2)(c)$. 
(including the genocide protocol), 86 collectively obliges states to refrain from causing, and to prevent and punish, such crimes, while ensuring strict observance of the undertakings by all national, regional and local public authorities and institutions. ${ }^{87}$ The GLR Protocol on Non-aggression and Mutual Defence also provides a legal basis for regional action against non-state armed forces within the region who are responsible for committing some of the crimes outlined above, and thus contributing to displacement. These frameworks set out regional co-operation platforms to fight negative forces, in recognition of the responsibility to protect civilians from serious violations.

In addition to introducing a protocol to deal with IDPs, the GLR process also introduced the Protocol on the Property Rights of Returning Populations, the Protocol on the Prevention and Suppression of Sexual Violence Against Women and Children, and protocols to address some of the root causes of flight in the GLR. ${ }^{88}$ This has worked towards ensuring effective transitional justice processes, reinforcing stability and security, and setting the pace for peacebuilding processes and reconstruction. ${ }^{89}$ These are important for maintaining peace and preventing any future displacements, while supporting durable solutions to displacement. The process is not perfect, or rather, as a laboratory for international justice, the GLR process is not yet perfected. Major setbacks stem from political contestations, which are heightened by racialized, ethnicized and sectarian policies of discrimination. This feeds into, and results from, marginalization and exclusion dating back to the colonial project of state-building within the region. ${ }^{90}$ This has paired with the incomplete transition to democracy, and state-polarity, reflected strongly in cross-border ethnic strife, to create a difficult cycle of pockets of instability. This volatility is exacerbated by the proliferation of small arms, exploitation of abundant natural resources and related impunity, which together remain a challenge to the successful completion of peacebuilding, reconstruction and finding durable solutions to internal displacement. ${ }^{91}$

Yet the GLR process also offers great opportunity, if its core strengths are promoted and appreciated. The imperfect early warning mechanism reflected in the GLR's follow-up institutions, such as the regional and national committees whose work feeds into each other, can be properly employed to ensure conflict prevention and the prevention of atrocity crimes by bolstering proper and rapid response capacities. ${ }^{92}$ These mechanisms can support

86 GLR Protocol on the Prevention and Punishment of the Crimes of Genocide, War Crimes and Crimes Against Humanity (29 November 2006), preamble and chap II.

87 Mulamula "Genocide prevention", above at note 80 at 4.

88 GLR Protocol on the Prevention and Suppression of Sexual Violence against Women and Children (30 November 2006); GLR Protocol on the Property Rights of Returning Persons (30 November 2006). See also above at note 78.

89 Clancy "Lessons from a state of flux", above at note 21 at $207-08$.

90 Mulamula "Genocide prevention", above at note 80 at 9 and 10.

91 Ibid.

92 Regional Committee for the Prevention and Punishment of the Crime of Genocide, War 
implementation follow-up of the GLR undertakings, and ensure compliance with peace agreements and other legal obligations, reflecting R2P's preventive dimensions. ${ }^{93}$ So far, the R2P reactive, and by extension reconstructive, dimension is reflected in the engagement on accountability for international crimes (including those resulting in, or arising from, forced displacement) within the GLR. This has been a springboard for international justice processes, including referrals to the International Criminal Court (ICC), and building national accountability frameworks, for instance, in Uganda and to an extent Kenya. ${ }^{94}$ The normative and ideological space created by the undertakings in the GLR Pact has been influenced by, and precipitated, continental shifts in tackling impunity for international crimes, including the AU normative and institutional systems. Although a link cannot easily be made, one can recognize the spirit of the pact within the Constitutive Act's interventionist stance, the AU Convention on Internal Displacement, the PSC architecture, and the AU humanitarian framework.

The GLR Pact has set forth a path for regionally addressing impunity related to international crimes (that in one way or another result in internal displacement). It has been a trailblazer in linking forced displacement to international crimes and has embraced the principle of collective responsibility for the protection of the most vulnerable civilians, including the displaced. ${ }^{95}$ For instance, when it comes to R2P triggers, its protection ambit is wider than similar norms within the Constitutive Act and framework. In addition to referring to mass atrocity crimes triggering R2P, it also refers to situations of gross violations of human rights, reflecting wider international legal protection. This ensures that most situations of internal displacement can fall directly within the protection ambit of the GLR framework. This is a significant achievement, limited only by the fact that the GLR framework does not specify what actions can be collectively taken by member states to address such violations when they occur, leaving discretion to an extraordinary summit. Whatever action is to be taken, complementarity with AU and UN peace and security frameworks is emphasized. ${ }^{96}$

contd

Crimes, Crimes Against Humanity and All Forms of Discrimination provided for by art 26 of the International Crimes (Genocide) Protocol as a collective early warning and prevention strategy; Clancy "Lessons from a state of flux", above at note 21 at 203.

93 Mulamula "Genocide prevention", above at note 80 at 9 and 10. Also see The Auschwitz Institute for Peace and Reconciliation "National mechanisms for the prevention of genocide and other atrocity crimes: Effective and sustainable prevention begins at home" (2015) at 2-3, available at: <http://www.auschwitzinstitute.org/wp-content/uploads /2015/06/AIPR_National_Mech_Booklet_2015.pdf> (last accessed 12 December 2020). Clancy "Lessons from a state of flux", above at note 21 at 209.

95 Ibid.

96 Id at 207; see GLR Protocol on Non-Aggression and Mutual Defence, art 4(8); GLR Pact, art $5(1)(d)$. 


\section{KENYA AND THE RESPONSIBILITY TO PROTECT IDPs}

The IDP framework and R2P principles in Africa reflect a restatement of existing international norms ${ }^{97}$ with a purpose and intent to highlight states' responsibility for the protection of vulnerable civilians, including the displaced. Acknowledging the relationship between conflict, forced displacement and the viability of peace and security, calls for the prescription of responsibility as a means of bolstering implementation of protection for the displaced, and accountability for mass atrocities that lead to forced displacement. This emphasis could bolster states' responsibility and collective accountability for IDP protection in Kenya. ${ }^{98}$

Despite criticisms, collaboration between regional and global efforts to halt the 2008 post-election violence worked quite well in Kenya, the one place where the UN has arguably discretely and successfully exercised the R2P. ${ }^{99}$ African regional and sub-regional operationalization of R2P, including efforts by the AU PSC's Panel of the Wise, were key to this. Equally, humanitarian efforts, which cascaded from Kenya's request for assistance within pillar two of R2P, addressed impacts of the crisis on civilians. The dimension to rebuild is reflected in peacebuilding efforts implemented through local and international collaboration. Some critics have overlooked these reactive and reconstructive dimensions of R2P, only highlighting the failure to prevent. Others narrowly focus on international elements, ${ }^{100}$ labelling Kenya a case of posthoc R2P, or concluding that the principle only served as background inspiration. ${ }^{101}$

Response strategies based on R2P recognize that regional and sub-regional institutions are important in meeting prevention and protection goals. ${ }^{102}$ The UN Charter contemplated the possibility of such a partnership between the UN Security Council and regional institutions. ${ }^{103}$ Settlement of disputes and / or enforcement action had been provided for within subsidiarity settings. ${ }^{104}$ Thus, addressing internal displacement within the African

97 These include international human rights law, humanitarian law and criminal law.

98 Evans The Responsibility to Protect, above at note 14 at 31-34 and 37-38; Bellamy Responsibility to Protect, above at note 44 at 31-32.

99 Cohen "Reconciling R2P", above at note 1 at 21; Sharma "The 2007-2008 post-election crisis", above at note 23 at 30 .

100 These include UN chap VII Security Council authorized intervention, international political pressure (including sanction threats), comments by the UNSG and the characterization of ethnic clashes as R2P. See also Cohen "Reconciling R2P", above at note 1 at 22.

101 J Junk "Bringing the non-coercive elements of R2P to the fore: The case of Kenya" (2016) 30/1 Global Society 54 at 57; T Weiss "Halting atrocities in Kenya" (2010, Global Centre for the Responsibility to Protect Great Decision Series no 2) at 24.

102 Implementing the Responsibility to Protect (report of the UNSG) GA A/63/677 (2009) at 9.

103 P Orchard "Making states accountable for deliberate forced displacement" (2019, World Refugee Council research paper no 17) at 8; Kuwali "Article 4(h), the responsibility", above at note 3 at 22 .

104 Iyi "Emerging powers", above at note 41 at 152; A Bellamy and P Williams "The new 
regional and sub-regional framework for advancing peace and security is logical. More importantly, paralysis within the UN on decisive and timely responses to mass atrocity crimes, has necessitated regional organizations to step in. Their familiarity with frameworks and regional contexts, proximity to issues being addressed, and the human rights obligations and international justice apparatus found within them, position them better for operationalizing R2P. ${ }^{105}$

\section{Characterizing R2P in Kenya}

Since, and long before, independence in 1963, Kenya has repeatedly experienced protracted violent internal displacement, triggered by politicized ethnic, border and land-related violence as well as banditry, natural disasters and development or conservation projects. ${ }^{106}$ Political violence in particular, or the threat or anticipation of it, has preceded and followed every election since Kenya's first multi-party elections in 1992. ${ }^{107}$ The worst occurred in the aftermath of disputed presidential elections in December 2007. At the height of this post-election violence, more than 1,110 people were killed and about 600,000 displaced. ${ }^{108}$ The riots, rape, assault, murder and forced displacement along ethnic lines reflected atrocity crimes. ${ }^{109}$ These crimes can be committed in all circumstances, but consist of specified acts, which can occur during widespread, or systematic attacks directed against a civilian population. Mass atrocity crimes constitute R2P trigger factors, even though they are not the only causes of internal displacement. Conceptually, international law provides a wider ambit for displacement relevant $\mathrm{R} 2 \mathrm{P}$ than the one reflected in the R2P doctrine. ${ }^{110}$ This wider ambit reflects protection responding to development induced displacement, climate change and socio-economic rights. It

contd

politics of protection: Côte d'Ivoire, Libya and the responsibility to protect" (2011) 87 International Affairs 825 at 846; UN Charter, chap VIII, arts 52(2) and 53(1).

105 Luck "Sovereignty, choice", above at note 3 at 63; Iyi, id at 169.

106 See Parliamentary Select Committee to Investigate Ethnic Clashes in Western and other parts of Kenya (Kiliku Report) (1992) at 67.

107 Ibid.

108 Reports on this number vary; assessments only considered IDPs in camps, omitting urban IDPs, those supported by relatives and those who crossed borders: Office of the AU Panel of African Eminent Personalities Back from the Brink: The 2008 Mediation Process and Reforms in Kenya (2008, AU) at 19; T Muriithi "Between reactive and proactive interventionism: The African Union Peace and Security Council's engagement in the Horn of Africa" (2012) 12/2 African Journal of Conflict Resolution 87 at 103; Report of the Commission of Enquiry into the Post Electoral Violence (CIPEV, The Waki Commission) (2008, Government of Kenya) at 282.

109 Mulamula "Genocide prevention", above at note 80 at 4; Kuwali "Article 4(h), the responsibility", above at note 3 at 22 and 23 .

110 Mooney "Something old, something new", above at note 1 at 67. See L Arbour "The responsibility to protect as a duty of care in international law and practice" (2008) 34/3 Review of International Studies 445 at 458. 
also encompasses apartheid, the persecution of an identifiable group and even the "deportation or forcible transfer of population", meaning the "forced displacement of the persons concerned by expulsion, or other coercive acts from the area in which they are lawfully present, without grounds permitted under international law". 111

Kenya is a member of the AU and the GLR. It has domesticated provisions of the GLR Pact, including the legally binding GLR IDP Protocol based substantially on the UNGP. ${ }^{112}$ It has also ratified the Kampala Convention, even though it is yet to implement it. Thus, in responding to the post-election violence, both organizations played an interventionist role, although to varying degrees and within different dimensions. The GLR response came from its representative, who initiated the first attempt to pacify the political crisis by characterizing what was happening in Kenya as "threats of genocide". ${ }^{113}$ This reflected the ethnic driven killings, displacements and hate campaigns taking place at the time, which would later be echoed in R2P calls by the UNSG. ${ }^{114}$ This reference to genocide was made as the ambassador and the GLR Troika representatives swiftly arrived in Nairobi in preparation for wider international initiatives to halt the violence. They simultaneously pushed for conflict resolution couched within the confines of the GLR Pact and its protocols. ${ }^{115}$ Unlike the AU, the GLR did not have an advanced institutional mechanism to engage with the situation. While it is likely that its normative framework influenced the post-crisis reconstruction frameworks and accountability approach employed, the political settlement came through AU structural efforts. ${ }^{116}$ After several unsuccessful initial attempts at negotiation by African leaders, the AU team, led by Kofi Annan and set up within the AU intervention framework, successfully took over. ${ }^{117}$

111 Mooney, id at 65. See Geneva Convention (IV) Relative to the Protection of Civilians in Time of War (12 August 1949) 973 UNTS 75, art 49; Protocol Additional to the Geneva Conventions of 12 August 1949; and the Second Geneva Protocol Relative to the Protection of Victims of Non-International Armed Conflicts (Protocol II) (8 June 1977) 1125 UNTS 609, art 17. The Rome Statute considers forcible population transfers as an act that may be a crime against humanity: Rome Statute of the International Criminal Court (17 July 1998) 2187 UNTS 90, art 7(1)(d).

112 Prevention, Protection and Assistance to Internally Displaced Persons and Affected Communities Act No 56 of 2012.

113 L Mulamula "Escalating violence, loss of lives and property in post-election Kenya" (ICGLR press release, 4 January 2008), available at: < https://reliefweb.int/report /kenya/escalating-violence-loss-lives-and-property-post-election-kenya> (last accessed 12 December 2020).

114 Implementing the Responsibility, above at note 102, para 55.

115 Mulamula "Genocide prevention", above at note 80 .

116 Clancy "Lessons from a state of flux", above at note 21 at 211.

117 Initial negotiations involved Archbishop Desmond Tutu, Ahmad Tejan Kabbah of Sierra Leone, Joaquim Chissano of Mozambique, Benjamin Mkapa of Tanzania, Ketumile Masire of Botswana and Kenneth Kaunda of Zambia (leaders of the Africa Forum of Former Heads of State) and Jendayi Fraser, US Assistant Secretary of State for Africa. 
The AU Panel of the Wise (Panel) is an organ of the PSC, operating alongside the African Standby Force and the Continental Early Warning System. ${ }^{118}$ Together, these organs of the PSC support the AU's mandate to intervene. ${ }^{119}$ The Panel was established to prevent and resolve peacefully conflicts on the continent by diplomatically assessing and intervening in situations to prevent further escalation. Together with the early warning system (an information gathering facility), the Panel is meant to work as a proactive conflict prevention resource. Yet, the Kenyan response was more reactive than proactive, only inevitably taking place after the conflict had escalated. The PSC's mandate, especially the use of the Panel, could and should have been used to prevent the escalation altogether. The Panel has been underutilized as a proactive intervention mechanism. Its strength lies in its political neutrality and independent modalities, which widen its remit for preventative diplomacy. If the Panel is supported with more political buy-in from wider AU peace and security structures, and not limited by political sensitivities, it can be a powerful tool for non-coercive collective responsibility within the wider AU intervention framework. ${ }^{120}$

R2P's reactive dimensions were operationalized through mediation by the Panel, in line with the intervention provisions of article $4(\mathrm{~h})$ of the Constitutive Act and article 11 of the PSC Protocol. The Panel's mandate was "to support efforts of the PSC and those of the Chairperson of the Commission, particularly in the area of conflict prevention". ${ }^{121}$ Since the conflict had escalated, the mandate also involved preventing further escalation and halting the crisis. The mediation was endorsed by the UN, and supported by critical diplomatic efforts that encouraged and pressured the feuding parties to mediate, giving momentum to the mediation. ${ }^{122}$ For instance, during the UNSG's Kenyan visit, he characterized the post-election ethnic clashes in Kenya as an R2P situation: "[t]he people and leaders of Kenya, particularly political leaders, have the duty, and the responsibility, to wake up and reverse this tragic path before it escalates into the horrors of mass killings and devastation we have witnessed in recent history. I have come to emphatically reiterate my fullest support to ... Kofi Annan”. ${ }^{123}$

118 This system provides analysis that can assist with preventive diplomacy and conflict prevention initiatives.

119 Muriithi "Between reactive and proactive", above at note 108 at 90.

120 Id at 107.

121 Ibid.

122 This rapid and co-ordinated reaction and pressure was praised as "a model of diplomatic action under the Responsibility to Protect" albeit after the event: Junk "Bringing the noncoercive elements", above at note 101 at 56-61. At the AU summit in Ethiopia, US Assistant Secretary of State for African Affairs, Jendayi Fraser, issued the first threat of forceful action against the opposition Kenyan parties by warning: "We'll find an international mechanism if they can't find it internally": T Tadesse "US sees 'ethnic cleansing' in Kenya” (30 January 2008) Reuters, available at: <https://uk.mobile.reuters.com/article /amp/idUSL2955076320080130> (last accessed 14 December 2020).

123 Unofficial transcript of UNSG's press conference, Nairobi, 1 February 2008, available at: 
As a politically mediated diplomatic solution, the response fell within the non-coercive dimension of responsibility to react, avoiding sanctions or military options, and making UN Security Council authorization unnecessary. ${ }^{124}$ A peace agreement between the two feuding parties, known as the Kenya National Dialogue and Reconciliation (KNDR) Agreement, was signed on 28 February 2008. The settled accord became a basis for a shared government and a nation-building process, with Mwai Kibaki as president and Raila Odinga as prime minister. Characterized by most as covert R2P, ${ }^{125} \mathrm{Mr}$ Annan concluded proudly when the agreement was signed: "when we talk of intervention, people think of the military ... But under R2P, force is a last resort. Political and diplomatic intervention is the first mechanism. And I think we've seen a successful example of its application [in Kenya]". ${ }^{126}$

\section{Agenda 2: Addressing internal displacement as prevention and reconstruction}

Kenya had to set up a system to respond internally to the political crisis, ensure that its security institutions and criminal justice framework were effective (thus promoting accountability) and then respond to the humanitarian crisis, including issues of internal displacement. The KNDR Agreement was underpinned by the National Accord and Reconciliation Act $(2008)^{127}$ and identified four critical areas for addressing causes of the crisis: Agenda 1: immediate action to stop violence and restore rights and liberties; Agenda 2: immediate action to address the humanitarian crisis and promote reconciliation; Agenda 3: overcoming the political crisis; and Agenda 4: addressing long term issues, including constitutional and legal reform matters.

The KNDR-led political agreement consequently established three commissions of enquiry to assess the electoral process, investigate the violence and promote accountability and reconciliation: the Truth, Justice and Reconciliation Commission; the Independent Review Commission on the

contd

<https://www.un.org/sg/en/content/sg/press-encounter/2008-02-01/secretary-generalspress-conference-unofficial-transcript> (last accessed 12 December 2020); Implementing the Responsibility, above at note 102, para 55.

124 R Thakur "Law, legitimacy and United Nations" (2010) 11/1 Melbourne Journal of International Law 1 at 5.

125 The French foreign minister was more explicit: "In the name of the responsibility to protect, it is urgent to help the people of Kenya. The United Nations Security Council must take up this question and act”: statement by B Kouchner, French Embassy, Nairobi, 31 January 2008 (copy on file with the author).

126 R Cohen "African genocide averted" (3 March 2008) New York Times, available at: <http:// www.nytimes.com/2008/03/03/opinion/03cohen.html> (last accessed 12 December 2020).

127 The National Accord and Reconciliation Act 2008 was entrenched in Kenya's 2010 Constitution and enacted by Parliament as the Constitution of Kenya (Amendment) Act 2008. 
General Elections (Kriegler Commission); and the Commission of Inquiry on Post-Election Violence (CIPEV, or the Waki Commission).

Internal displacement was clearly recognized within Agenda 2 as a key aspect of the humanitarian crisis and it had to be resolved immediately to halt humanitarian suffering and promote reconciliation as a way of preventing future conflicts. This aspect ties closely into the AU's peacebuilding and civilian protection agenda, as well as the international justice framework of the GLR process. These frameworks recognize that addressing forced displacement, including individual and collective accountability, is an important approach for reconciliation and reconstruction, thus preventing future conflicts. The UNGP reflect this by promoting durable solutions for internal displacement as a means of ensuring peace and stability, above and beyond preventing and addressing displacement. Implementation of agenda 2 was thus aimed at mitigating the effects of displacement and ensuring that internal displacement did not become protracted. ${ }^{128}$ The process of building peace post-conflict or post-crisis, is closely tied to how the situation of displacement within the relevant society is addressed. This emphasizes that, in building stable societies, issues of forced displacement must be addressed durably, and the internally displaced as well as host communities must be involved in devising processes to address them. ${ }^{129}$ Most importantly, determination of peace processes and peace agreements cannot be complete without engaging with the issue of internal displacement or any other form of displacement, while ensuring that the communities themselves are at the heart of the discussion. The displacement-peacebuilding nexus ties in very well with the third dimension of R2P on rebuilding.

The protection of civilians within this context must reflect finding durable solutions to internal displacement, through return, local integration or resettlement. Agenda 2 of the KNDR Agreement prioritized dealing with the displacement crisis by mandating an investigation into the post-election violence that caused mass displacement. CIPEV was to investigate the facts and surrounding circumstances related to the violence that followed the elections and make recommendations to the Truth, Justice and Reconciliation Commission to prevent any recurrence of the violence, including issues of displacement. In the process, legal and policy frameworks were adopted for IDPs, and criminal justice accountability was recommended for those who were involved in instigating crimes. The latter would lead to an ICC referral and precede what would become an international criminal justice option within the

128 P Kamungi "National response to internal displacement: Achievements, challenges and lessons from Kenya" in E Ferris, E Mooney and C Stark From Responsibility to Response: Assessing National Approaches to Internal Displacement (2011, Brookings-LSE) 231 at 236; Annotated Agenda II, measures signed by the parties (14 January 2008).

129 W Kälin Durable Solutions for Internally Displaced Persons: An Essential Dimension of Peacebuilding (2008, Brookings) at 8; UNGP, principle 28(2); GLR IDP Protocol, art 28(2); Kampala Convention, art 11(2). 
R2P toolkit. ${ }^{130}$ Both the IDP and accountability systems emanated from the GLR process and its frameworks, emphasising its normative and conceptual contribution to rebuilding Kenya.

CIPEV's report highlighted that finding durable solutions for internal displacement was key for achieving peace and addressing the humanitarian crisis. Prioritising IDPs' needs and rights (protection) and providing proper support for return, re-integration and resettlement were important. CIPEV considered IDPs to be the human face of the consequences of post-election violence, and the resolution of their plight would be a measure and indication of the government's response to the violence as part of its state responsibility. Accordingly, a team was put together to forge a National Reconciliation and Emergency Social and Economic Recovery Strategy. ${ }^{131}$ As part of the strategy, and in line with the KNDR Agreement, the government undertook to provide protection and security, and encourage local integration, return or resettlement and rehabilitation of IDPs. It would also provide basic services for those in camps and provide information, including ensuring close linkages and work with national and international assistance to enhance effective response, national dialogue and reconciliation. ${ }^{132}$

Return was obviously prioritized above other solutions because it was easier, quicker and cheaper. However, this political enthusiasm did not translate into effective processes; in fact, the way return was implemented left much to be desired. From the beginning, the operation was marred by haste, coercion, inefficiency, nepotism, corruption and lack of consideration or even consultation with the affected populations, going against legal requirements. ${ }^{133}$ To this end, the return process failed the durability test, seeing that most IDPs were eventually re-displaced upon their return, or did not effectively benefit from return packages. This, coupled with unresolved and outstanding land, property and security issues, forced them eventually to settle within the urban poor. ${ }^{134}$ Due to this, the question of preventing future displacement remains open. Perhaps clearly situating the response within the KNDR

130 Waki Commission Report, above at note 108 at 271 and 473; Kenya International Crimes Act No 16 of 2008 (domesticating ICC Rome Statute); Special Tribunal for Kenya.

131 National Accord Implementation Committee "National reconciliation and emergency social and economic recovery strategy" (March 2008) at iv.

132 Waki Commission Report, above at note 108 at 282. Initiatives launched to encourage IDPs to return included: Operation Return Home (Rudi Nyumbani), Operation Reconstruction (Tujenge Pamoja) to reconstruct damaged houses and infrastructure, and Operation Good Neighbourliness (Ujirani Mwema) to promote healing and reconciliation.

133 Kampala Convention, art 11(1) and (2); Kamungi "National response", above at note 128 at 232.

134 Kamungi, ibid; UNGP, principles 28 and 29; and GLR IDP Protocol, art 29(2); Kampala Convention, art 11(4) and (5); P Kamungi "The politics of displacement in multiparty Kenya” in P Kagwanja and R Southall Kenya's Uncertain Democracy: The Electoral crisis of 2008 (2010, Routledge) 86 at 96-97. See also norms on remedies and restitution in the Kampala Convention, arts 12(1), 12(2) and 8(3)(e). 
Agreement would have elevated the R2P spirit underlying the agreement and emphasized effective prevention, protection and accountable rebuilding, including return, thus lending credence to the process. When one weighs this part of the Kenyan response against the R2P framework, it fails miserably.

R2P emphasizes a dimension to prevent crises. Within the context of internal displacement, that reflects identifying and preventing trigger factors that lead to displacement. The future of protecting the most vulnerable during a crisis is most dependent on a state's capacity to identify and prevent or halt possible atrocity crimes. For this matter, national bodies have been set up to provide early warning support within the GLR. These bodies reflect the GLR regional follow-up mechanisms, specifically the regional committees, and the parallel national committees that are provided for by the GLR Genocide Protocol. ${ }^{135}$ The Kenyan National Committee for the Prevention and Punishment of the Crime of Genocide, War Crimes, Crimes Against Humanity and All Forms of Discrimination (National Committee) was launched in 2012 and is situated within the Ministry of Foreign Affairs as part of the function of the Office of the Great Lakes. ${ }^{136}$ Potential for the committee to play a strong part in early warning or prevention lies in its composition of different players from civil society, academia, government ministries and local or religious leadership. These groups of people have access to, and engage with, issues on the ground and within communities. They are well privileged to sensitize communities, analyse new and emerging threats, and influence the process of prevention by feeding back into the national and GLR regional early warning framework on atrocity prevention. ${ }^{137}$

However, most of these national committees are yet to achieve full capacity; in Kenya, the National Committee has still not taken off properly. There is also limited information on who does what and when. Proper training on the UN atrocity crimes framework needs to be implemented constantly and these committees need to have adequate technical and financial capacity to carry out their roles. Most importantly, it is not clear whether their expertise and context is properly tapped into when circumstances require it. For instance, there is no obvious link between the work that the National Committee does and the work done by institutions set up by the KNDR Agreement on addressing the post-election violence and preventing any future crisis that would result in displacement. ${ }^{138}$ Given that most members of the National Committee are drawn from institutions and ministries set up under the KNDR Agreement, the link should be automatically obvious. ${ }^{139}$ Yet, besides

135 Clancy "Lessons from a state of flux", above at note 21 at 203.

136 GLR Pact, art 27; Auschwitz Institute "National mechanisms", above at note 93 at 5-6.

137 Kampala Convention, art 4(2).

138 These institutions include the National Steering Committee on Peace-Building and Conflict Management and a network of district peace committees cascading from the Inter-Governmental Authority for Development's Conflict Early Warning and Response Mechanism.

139 Members are drawn from the: Ministry of Provincial Administration and Internal 
the Kenyan IDP Act of $2012^{140}$ and draft IDP policy, it remains difficult to link the early warning and legal protection system emanating from the GLR process directly to efforts and mechanisms set up in Kenya for collectively resolving the crisis and consequent displacement. ${ }^{141}$ The AU system was more visible in resolving the crisis, but its institutional system is not streamlined locally; for instance the Continental Early Warning System has not influenced early warning in Kenya, neither was reconstruction through article 14 of PSC explored. This mix of normative and institutional options has left operationalization, applicability and implementation gaps in collectively protecting the internally displaced.

The Kenyan experience presents difficulties associated with an attempt to reconcile R2P with IDP protection. Kenya inadequately provided an illustration of what R2P can deliver in situations of internal displacement. Unfortunately, that intervention avoided linking the response structure to the UNGP, the GLR framework, the AU framework or express R2P. This limited any future option for easily relying on it within these contexts. In fact, the UNGP and internal displacement only indirectly find a place within CIPEV's report and recommendations, with the KNDR Agreement skirting around and combining IDPs with other humanitarian issues. Because of this, linking IDP issues to R2P principles underlying the peace agreement proves to be even more difficult, and this limits any attempts collectively to oblige Kenya to protect IDPs within this context. These factors make it difficult to replicate the Kenyan approach in circumstances that are different from those in Kenya. It becomes very clear that "the power of R2P is political, not legal". ${ }^{142}$ R2P has been instrumental in opening up the necessary political space to spell out procedures, and thereby also begin to open up new possibilities for collective international action, which situations of internal displacement may demand in exceptional circumstances. However, as seen in Kenya, avoiding a legal-oriented approach becomes an easier, less messy, political option for obtaining international support. It also limits R2P outcomes for IDPs to humanitarian assistance, as opposed to legal protection, which would have been a state obligation, failure of which would justify collective action. This

contd

Security; Ministry of Justice, National Cohesion and Constitutional Affairs; State Law Office; Director of Public Prosecutions; Kenya Police; National Cohesion and Integration Commission; Kenya National Commission on Human Rights; Truth, Justice and Reconciliation Commission; Law Society of Kenya; International Commission of Jurists; Federation of Women's Lawyers - Kenya; Peace Net Kenya; Kenya Red Cross; and National Coordinator of the Great Lakes Region (who is the Committee's Coordinator).

140 Above at note 112.

141 Auschwitz Institute "National mechanisms", above at note 93 at 5-6.

142 EC Luck "The United Nations and the responsibility to protect" (The Stanley Foundation policy analysis brief, August 2008) at $6-8$, available at: $<$ https://stanleycenter.org/publ ications/pab/LuckPAB808.pdf> (last accessed 12 December 2020). 
also means that R2P within displacement situations will only work where and when it is politically viable.

\section{CONCLUSION}

The reality of internal displacement in Africa, and the human rights violations that accompany and cause it, requires response capabilities that find preserve in collective accountability underlined within R2P. The in-state nature of internal displacement, the fact that basic responsibility for protecting the internally displaced rests with the states within which the IDPs find themselves, and the often-broken relationship, or incapacity to protect that leads to, or results from such displacement, have unlocked opportunities leading to the call for the reconceptualization of sovereignty itself.

International human rights and humanitarian law already reflect the criminalization and prohibition of forced displacement. This includes the protection of specific categories of the vulnerable from evictions that are prohibited under international law, recognition that all human beings (including IDPs) are protected under human rights law, and states' obligation to take responsibility for consequences of internal displacement and enjoyment of other entitlements. By reflecting these provisions, as compiled within the UNGP, and being guided by them, both the AU and GLR framework were influencing, but also influenced by, existing norms. Perhaps what they offer is a more concise, codified, collectively binding and elaborated version of these norms, specific to the African context. ${ }^{143}$

Yet, IDP protection couched within R2P is still theoretical and rare in Africa. ${ }^{144}$ This could be because of its limited and narrow application to atrocity crimes. The side-lining of the UNGP in R2P contexts and the exclusion of disaster IDPs are also problematic, but politically expedient because they limit situations within which R2P can be invoked. ${ }^{145}$ The most contentious aspect here is the dichotomy between human rights and the humanitarian-oriented protection of IDPs. R2P re-emphasizes the politics of demanding IDP protection from the state and threats of collective intervention, as opposed to easier and less political, humanitarian assistance. This is compounded by the fact that R2P is often reduced to military intervention. The obvious limited confidence in, and tensions brought on by, military action, and the fact that noncoercive elements of R2P remain ignored, has contributed to the norm having limited relevance in IDP situations. ${ }^{146}$ This disregards the fact that all R2P pillars and dimensions are essential, and can be implemented together or separately within the context of internal displacement.

143 Compilation and Analysis of Legal Norms, E/CN.4/1996/52/Add2 (1995); and Compilation and Analysis of Legal Norms, part II, E/CN.4/1998/63/Add.1 (1998).

144 CCR "Africa's responsibility to protect", above at note 45 at 21.

145 Cohen "Reconciling R2P", above at note 1 at 22.

146 Ibid. 
The politicization of the approach, and the lack of clarity of the concept itself has opened it for criticism, but therein lies an opportunity to elaborate it to work in the context of IDPs. Besides, in Africa, the concept is not vague because it is clarified and reflected in legal frameworks, both at sub-regional and regional level, creating legal obligations. Most scepticism surrounds African peace-keeping and intervention forces and it is argued that collective military action by these efforts is limited by both resources and capacity. ${ }^{147}$ Yet this should not be an issue if Africa prioritizes pillar one, two and the noncoercive elements of pillar three, as it has so far. This could go hand in hand with Africa building its intervention force. Perhaps, the biggest issue remains the residual sovereignty that can obstruct future attempts to promote collective action, limiting it to lip service; however, as we have seen in Kenya, where non-coercive aspects are operationalized, intervention works well. ${ }^{148}$ Notably, operationalizing R2P regionally might be more effective, and less politicized, due to familiarity with actors and frameworks. It would also evoke less suspicion and be more amenable to regional diplomatic realities.

Of note is the Kenyan scenario where, despite obvious challenges, R2P was "successfully" implemented because, from the onset, Kenya accepted regional and international support in the form of mediation and did not raise the sovereignty cloak. More importantly, because the intervention set out in Kenya reflected dialogic (non-coercive) elements of R2P, this limited politicization of the issue and the UNSG easily bypassed UN Security Council authorization as required by article VII of the UN Charter. ${ }^{149}$ Additionally, the intervention happened within the context of the regionally championed AU security apparatus (the Panel), with only support from the UN. This regionalized form of intervention, perhaps lent credence to the mediators, who were mostly current or former African leaders and limited the distrust that is usually levelled against international interventions.

R2P can only succeed in bolstering the implementation of IDP protection frameworks if there is political will for states to subject themselves to collective accountability. The mere existence of legal, policy and institutional capabilities does not in itself guarantee adherence to such standards. ${ }^{150}$ For instance, in Kenya, internal demands for peace, and political willingness to settle, worked better than an imposed external solution would have done. Importantly, African initiatives to bolster protection for IDPs must reconcile their approach to operationalizing R2P with the cleavages that exist within Africa's political, institutional and normative compliance mechanisms. Weak responses on the ground and the very theoretical reality of intervention to protect IDPs, requires more preventative than reactive solutions. This can be achieved by prioritizing the prevention of conflict, building stronger early

147 Ibid.

148 Weiss "Halting atrocities", above at note 101 at 21.

149 Cohen "Reconciling R2P", above at note 1 at 22.

150 Ibid; Weiss "Halting atrocities", above at note 101 at 28. 
warning mechanisms, promoting transparency, facilitating democratic governance, and building political and legal consensus on relevant intervention measures where national governments have failed or are unable to perform accordingly. ${ }^{151}$ Such measures need not be only militaristic and coercive. Perhaps it is important to engage with non-coercive approaches as displayed in Kenya. Such measures must also go beyond the emergency phase, to address the build-up to a crisis, the aftermath and root causes.

\section{CONFLICTS OF INTEREST}

None 